JANENE CULUMBER

\title{
PHYSICIAN EMR ADOPTION IN AN ACADEMIC SETTING ${ }^{1}$
}

This data confirms my worst fears...the physicians are not ready for change. How can I move this organization to electronic workflows if key leaders needing to change aren't ready?

Mark Hulse, Chief Information Officer at Moffitt Cancer Center wondered out loud as he stared at the results of the survey used to determine organizational readiness for change. Much about this implementation seemed to be different from his prior experiences: the academic setting, the physician led leadership structure, the regulatory requirements driving change, and the government incentives to reduce the financial burden of implementation.

Hulse's decision of how to proceed was influenced by a number of issues. First, electronic clinical documentation was implemented but very few physicians had adopted the technology, as it was more cumbersome then their current process. Attempts to push adoption had resulted in considerable frustration from the physicians. Second, the organization was running out of time. To earn government incentives for meaningful use (approximately \$6 million), certain aspects of the electronic records had to be in place in six months. The project was plodding along, but it was feasible to continue with the current path and implement just enough to meet the requirements for year 1 . But after the initial year, the next phase would be Computerized Provider Order Entry, requiring even further adoption and significant clinical workflow changes. The risks would continue to compound making it challenging to hit stage 1 in time to achieve any incentives.

Both Hulse and Dr. Phil Smith, the Chief Medical Information Officer, believed there was another alternative. The organization needed to change its view from an IT driven project to an institutional change in clinical and operational workflows. But, that would entail a much longer process and would require the organization to forgo the significant financial incentives. Would the executive leadership even entertain such an idea?

Hulse and Smith stared at each other; they both knew neither proposition was without great risk. They were already receiving angry emails from physicians and the executive team was anxious, to say the least.

Hulse sighed, "This is not going to be an easy decision to make.”

\footnotetext{
${ }^{1}$ Copyright $($ ) 2016, Janene Culumber. This case was prepared for the purpose of class discussion, and not to illustrate the effective or ineffective handling of an administrative situation. Names and some information have been disguised. This case is published under a Creative Commons BY-NC license. Permission is granted to copy and distribute this case for non-commercial purposes, in both printed and electronic formats.
} 


\section{Healthcare Provider Industry}

At the time of the case, Moffitt Cancer Center (Moffitt) was a large healthcare organization that included a 206 bed hospital, a large physician practice and a research institute; all of which were dedicated to the mission of contributing to the prevention and cure of cancer. The healthcare industry was tumultuous during this time period as there was tremendous change in healthcare reform legislation at both the state and federal level. Each of these reforms created their own set of challenges in terms of implementation cost, adoption and competitive market position. To mitigate some of the pressures of all this change, the government put in place incentives to encourage early adopters. In situations where there were no government incentives, the market was reacting and creating its own incentives to showcase quality and improve cost effectiveness. Reducing costs and improving quality quickly became market imperatives.

At a time when investments in infrastructure were high, the government payers were reducing reimbursement creating tremendous budgetary pressures on healthcare provider organizations. Because the healthcare market was so fragmented, some markets reacted more quickly to the changes than others. Across the United States, large healthcare organizations began to merge or create unique partnerships as scale became more critical to success.

Of the many legislative changes taking place during this time period; two were particularly impactful to Moffitt and to the decision Hulse was facing: The Health Information Technology for Economic and Clinical Health (HITECH) Act and the Affordable Care Act (ACA).

\section{HITECH Act}

The HITECH Act was enacted in February 2009 as part of the American Recovery and Reinvestment Act (widely known as the stimulus bill). Its purpose was to enable the meaningful use of interoperable electronic health records throughout the healthcare systems in the United States. It supported the efforts of the Centers for Medicare and Medicaid Services (CMS) meaningful use program as well as the Office of National Coordinator for Health IT's (ONC) efforts to create interoperability of health records. Congress passed the law out of concern about data showing that simply having an electronic system was not adequate to improve care (Jha, 2010). Electronic Medical Records (EMRs), also referred to as Electronic Health Records (EHRs), needed to be used meaningfully to improve quality outcomes.

Meaningful use provisions were designed to align with health outcomes policy priorities ("Meaningful Use," 2012):

1. Improve quality, safety, efficiency, and reduce health disparities

2. Engage patients and families in their health

3. Improve care coordination

4. Improve population and public health

5. Ensure adequate privacy and security protection for personal health information

The requirements to meet the meaningful use provisions were complex and costly. In order to encourage participation in EHR adoption and to implement the complex provisions; meaningful use was developed as a phased approach. In addition, CMS offered incentives to both eligible hospitals and eligible professionals (physicians) for early adoption. The requirements and related incentives were different for each stage depending on whether the recipient was a physician practice or a hospital. Moffitt was both and was therefore required to implement both sets of rules. However, because of Moffitt hospital's unique reimbursement from CMS (see discussion about Moffitt Cancer Center), Moffitt was only eligible for incentives under the Eligible Professionals (Physician Practice) rules. However, the penalties would 
ultimately apply to Moffitt under both sets of rules. See Exhibit 1 for details of the incentives available under Meaningful Use for Eligible Professionals.

On September 26, 2010, CMS/ONC final rules relating to meaningful use measures and standards became effective for Stage 1. The Stage 1 requirements were divided into 15 core set objectives and 10 menu set objectives. On August 23, 2012, CMS released the final requirements for Stage 2 meaningful use and the criteria that electronic health records were required to meet to achieve certification ("Meaningful Use," 2012). Stage 2 expanded on the criteria in Stage 1 and delayed the onset of Stage 2 meaningful use criteria until 2014. See Exhibit 2 for details of the Stage 1 versus Stage 2 requirements comparison for eligible professionals.

The complexity of the changes required, coupled with the pace with which the regulations were driving the changes, put tremendous pressure on clinicians and hospitals alike. Clinicians were required to change the way they practiced from largely paper based to electronic. If systems were not properly designed or implemented, the consequences could be significant (Jha, 2010). These barriers required engagement on the part of physicians, administrators and patients. In order to be sustainable, new payment models were needed to reward quality and efficiency (Jha, 2010).

Hulse was feeling the pressure particularly with regards to the amount of change that was going to be required. Moffitt had implemented the EMR, but were not using it meaningfully, at least according to the definitions and standards set by the Act. Many challenges were on the horizon.

\section{The Affordable Care Act}

The Patient Protection and Affordable Care Act (the Affordable Care Act or ACA) was enacted on March $23^{\text {rd }}$, 2010. The ACA had several major aims (Rosenbaum, 2011):

- Universal coverage through shared responsibility among government, individuals and employers

- Improve fairness, quality and affordability of health insurance coverage

- Improve healthcare value, quality and efficiency

- Strengthen primary care access

- To make strategic investments in the public's health

The key aim impacting Moffitt at the time of this case study was to improve healthcare value, quality and efficiency. The Affordable Care Act introduced broad changes to CMS and State Medicaid programs to pilot new payment and service delivery models, such as medical homes, accountable care organizations, payments for episodes of care and bundled payments. These changes were intended to drive healthcare systems into operating in a more clinically integrated way, measure health systems and physicians' quality performance and target quality improvement in chronic disease management (Rosenbaum, 2011).

These efforts would require hospitals and clinicians to define and measure quality, and to better understand where improvements in care management and cost could be made. Unfortunately, the analytic abilities of most institutions were hindered by their ability to capture discrete data elements and to organize the data in a usable way. In general, the information captured was restricted to billing and diagnosis codes which did not capture the full story regarding the patient's health. In addition, each institution was limited to the data related to care provided at their institution, not the entire continuum of care. Capturing discrete data elements in order to prove quality and analyze efficiencies was becoming a strategic imperative at most healthcare organizations. 
Moffitt needed more discrete data elements, not only to improve healthcare value, but also to improve their ability to conduct comparative effectiveness research; both of which would increase Moffitt's competitive position and its reputation as a leader in cancer research. At the time of the case, most physicians continued to dictate their notes in the medical record which prevented Moffitt from capturing the discrete data elements needed.

\section{Moffitt Cancer Center and Research Institute}

The H. Lee Moffitt Cancer Center and Research Institute, Inc. (Moffitt) was opened in 1986 as a nonprofit organization with a mission to contribute to the prevention and cure of cancer. By 2013, Moffitt had grown to a 206-bed cancer hospital serving close to 9,500 patients a year, an outpatient clinic with multiple locations providing approximately 400,000 patient visits a year, and a research institute with grant funding primarily from the federal government totaling \$90 million per year. Moffitt's consolidated annual budget totaled $\$ 800$ million per year of which roughly $80 \%$ was associated with its clinical mission while the remaining 20\% was dedicated to research. Of Moffitt's clinical revenues, $70 \%$ were made up of outpatient clinical visits and ancillary services while the remaining 30\% were associated with hospital admissions.

As a non-profit organization, Moffitt reinvested its earnings toward its mission. As such, Moffitt's consolidated annual net operating margins generally fell somewhere between $1 \%$ and break-even. Moffitt's clinical revenues were invested in the research mission as grant funding was not sufficient to cover the cost of research. As such, any pressures on clinical margins had a significant impact on the research mission.

Although Moffitt was a stand-alone non-profit organization, it was created by the State of Florida legislature with a mission to serve the state's cancer needs. Moffitt was not a government entity but was considered an instrumentality of the state and as such, was able to receive annual funding from general appropriations, as well as funding from cigarette tax revenues. Cigarette tax funding was restricted to construct new facilities, while the general appropriation received by Moffitt went toward training future cancer physicians and researchers, and totaled approximately \$13 million annually.

Because Moffitt's clinical focus was entirely centered on caring for patients with a cancer diagnosis, Moffitt received unique reimbursement from Medicare in comparison to hospitals that provided general patient care services. Moffitt's reimbursement of care from Medicare was roughly based on the cost to treat patients and included some provisions for capital costs. The cost basis payment provided to Moffitt was settled up with Medicare each year after filing a cost report. It was for this reason that Moffitt was not eligible to receive incentives for meaningful use under the hospital based provisions. Some of the costs of implementing the measures at the hospital would be included in the Medicare reimbursement through the cost report.

Moffitt was a premier cancer research institution receiving the coveted National Cancer Institute (NCI) designation as a comprehensive cancer center. This allowed Moffitt to attract some of the world's most renowned leaders in cancer care and research. Moffitt's affiliation with the University of South Florida (USF) allowed its physicians and researchers to hold faculty appointments at USF. As such, Moffitt was unique in that it looked and acted much more like an academic medical center than a specialty hospital with a research mission.

Moffitt's hospital and clinic enterprise was also unique in comparison to a general hospital. Not only was Moffitt highly specialized in treating cancer care; they were subspecialized by disease site. The physicians at Moffitt didn't treat cancer in general, they were specialized in a specific area of cancer. The clinics were organized into departments which were led by a Physician Department Chair. The Department Chair 
was responsible for the clinic operations, the research success of its members and the strategic direction of the department. This was one of the keys to Moffitt's success, a truly interdisciplinary approach to cancer care and research. However, it created challenges from a standardization and efficiency standpoint. See Exhibit 3 for a listing of Moffitt's patient care programs. Patient care programs usually fell within a department and in some cases were large enough to be the only focus of a department.

At the time of this case, Moffitt's newly appointed CEO had been in place for about a year. He was a world-renowned physician and clinical researcher in the field of hematologic malignancies (blood cancers). He had spent his first year as CEO working with his leadership team to develop a new strategic plan for Moffitt. The plan was bold and was going to require a tremendous amount of change over the next few years. The leadership team at Moffitt had great confidence in the direction of the strategic plan and particularly in its new CEO. He was extremely well respected by all at Moffitt and was a proven leader particularly in his ability to shepherd change.

\section{The Survey}

Hulse stared at the survey results on his computer. The survey was administered to determine the organization's readiness for change. The results showed that the physicians, on average, were not in sync with the leadership team. In addition, the clinical leaders were in the bottom quartile in the areas of: coordination and integration, and managing change and capability development. In fact, many of the areas where the survey results were the poorest pointed to the difficulties he faced. Four of the five lowest scores in the survey related in some way to the responder's feeling that the way things were done at Moffitt did not make it easy to change, that change in general was met with resistance, and that coordination between departments was poor.

This was not entirely surprising to Hulse; he had experienced this first hand. The first phase of the implementation of the electronic medical record had been completed a year ago, but very few physicians had fully adopted the technology. Initially, the EMR was seen more as a clinical data repository, useful for retrieving lab results, or seeing dictated and transcribed notes. Moffitt had yet to leverage the full utility of an EMR to facilitate clinical workflow and improve the coordination of a patient's care. This would require entering all clinical documentation electronically, and adopting the EMR as the official medical record at Moffitt.

\section{Change Management}

Moffitt was certainly not alone; many organizations had documented their own struggles. But, Moffitt was unique in many ways. For one, Moffitt acts much like an academic medical center. Almost all of its physicians are focused on both research and patient care. As such, they spent anywhere from 50 to 80 percent of their time in the clinics. The remaining time was focused on research. Any additional time added to their clinic directly impacted their ability to focus on their research goals. Promotion and tenure was based primarily on their research efforts. Finally, each department (clinic) was led by a physician leader. The administrators and nurse leaders in the departments reported directly to the physician. As a result, each department operated a bit differently, and standardization across departments was an ongoing challenge faced by the leadership team.

Hulse reflected on the history of the previous implementation. The organization used a committee structure and had a project manager assigned to plan. In addition, they had included four physician champions, representative of the major types of clinicians at Moffitt (oncologist, hematologic oncologist, oncology surgeon and a radiation oncologist). These physician champions participated in the EMR 
Steering Committee and a Physician Champion Committee. The information technology team had run major design decisions by them and had made changes based on their input. After go-live the IT team had listened to their concerns and accommodated their feedback where possible.

After several months of struggling to no avail, Hulse sought out and hired an expert with experience in EMR adoption, Dr. Phil Smith. Dr. Smith had previously served as the Chief Medical Informatics Officer for the Adventist Health System. During that time he had implemented EMRs and Computerized Provider Order Entry (CPOE) at dozens of community hospitals. Hulse first brought on Smith as a consultant in February 2013, and later hired him as Moffitt's CMIO.

\section{Project Phases}

After two months of evaluation, Dr. Smith and Mark launched the EMR refocus project with the goal of obtaining $90 \%$ adoption by physicians by the end of January 2014. It was now August 2013, and with the support and leadership of Moffitt's Physician in Chief (PIC) and CEO, the project was gaining traction. The PIC volunteered his department, Sarcoma, to be the pilot group. Dr. Smith and the IT team under Hulse's leadership was able to work with the Sarcoma department to create significant changes in workflow and improvements in the outbound notes that were considerable. Slowly but surely, department chairs began to volunteer their departments to go next and the change began to take hold. By now, a few of the 13 departments had achieved full adoption, bringing Moffitt's overall physician adoption to approximately $14 \%$. While still small, the momentum was building quickly and was following the technology S-curve model of adoption nicely (see Exhibit 4). It appeared that Moffitt was on track to reach their adoption goal.

This initial phase, phase zero, was just the beginning. The next major milestones were the implementation of medication reconciliation in the clinics (it had already been adopted in the inpatient units), meaningful use stage one (which was underway) and CPOE. All were required by the federal HITECH Act and Moffitt was pushing up against the deadlines for achieving any of the incentive dollars being offered. Because of Moffitt's unique reimbursement status with CMS, they were not eligible for the hospital-based incentives, however they would likely be subject to the penalties. Moffitt was, however, eligible for the provider-based incentives and they had approximately 160 eligible providers in 2013. If they were to reach Stage 1 by 2014; their total incentives over a five-year period would amount to $\$ 6.1$ million. If they were to miss the 2014 deadline, they could still receive incentives of \$3.8 million as long as they reached Stage1 by 2015. If they missed that deadline, they would be subject to penalties.

\section{The Decision}

Hulse stared at the IT project plan with all of its phases. It was a solid project plan that would enable the organization to meet Stage 1 by 2014 and CPOE in the required time frame, if successful. They leveraged physician champions, and had several committees to monitor progress and address roadblocks. While Moffitt had engaged physicians previously, Hulse felt that this time would be different as so much had been learned during the EMR refocus project from both his team and the physician leadership. Although every plan had its pitfalls, this one seemed like a reasonable approach and had incorporated lessons learned.

Hulse glanced at Dr. Smith. CPOE was different, and while one could argue that every project was different, based on Hulse's experiences (the most recent one included) this one had some significant change management challenges. As Hulse put it,

We were extremely concerned about the workflow changes that would result from moving from paper for orders to using the computer. For example, in the existing 
environment, the nurses would draw up the orders and make sure they happened. In the future state environment, the physicians would need to place the orders in the computers which is something they felt would slow them down. The system would then automatically generate instructions and complete the follow through. While this would free up the nurses, we recognized that the nurses might not view it as a positive change. They were in control of this process currently and in the future state would need to relinquish control.

While this may seem like a small change on the surface, the detailed algorithms that would need to be built were complex. In addition, each department and clinic had its own way of processing orders and in many cases, its own unique order sets. The workflow in each clinic was different, and the responsibilities of the nurses and medical assistants in each department also varied. Everyone had their own unique way of processing the various orders (radiology, chemotherapy and laboratory). Hulse was familiar with the horror stories of failed CPOE implementations such as that at Cedars-Sinai Medical Center in LA. As reported on January 22 ${ }^{\text {nd }}$, 2003 by the Los Angeles Times by staff writer, Charles Ornstein,

Cedars-Sinai Medical Center, the largest private hospital in the West, is suspending use of a multimillion-dollar computerized system for doctors' orders after hundreds of physicians complained that it was endangering patient safety and required too much work.

Would the current IT plan work or should they pursue another strategy? Dr. Smith recognized that look. They both new this was going to be a huge challenge. Dr. Smith supported Hulse's concerns,

This was going to require a cultural change. It couldn’t be viewed as an information technology project or a federally mandated project. It needed to be viewed as a financial, operational and clinical change in the way care at Moffitt Cancer Center was delivered for the benefit of the patients.

The other alternative Hulse and Smith were considering was to have the organization focus on a plan that would change the operational workflows of the organization, in which IT would be a subset of the overall project. The idea was that all of Moffitt's leadership would need to work together to define guiding principles that would paint the picture of the desired outcome. From the guiding principles, initiative goals would be established that were measureable. For example, a guiding principle would be: Moffitt maintains an accurate list of medications upon admission and discharge from inpatient care. Where the measurement would be: a physician completes admission medication reconciliation within 12 hours of patient discharge on $>90 \%$ of inpatient encounters. From there a team of folks from operations and process excellence (Moffitt's version of lean process improvement) and IT would design workflows and system design changes to meet those goals. The information technology design changes would be implemented once these processes were completed.

In order for the alternative strategy to be successful, the leadership was going to have to look hard at everything currently on their plates and make some tough decisions about priorities. This was going to involve nearly every department in Moffitt and rather than the current four physician champions; one or two would need to be assigned from each program. In addition, this kind of change, re-developing workflows across the entire clinic spectrum, was going to take a considerable amount of time. It was unlikely that Moffitt would be able to achieve the Stage 1 requirements in 2014 if they moved in this 
direction. It was also a stretch to think they would achieve them in 2015. In fact, moving in this direction would push the organization up against the penalty phase of the HITECH requirements.

Hulse weighed the options. They could implement the current version of the IT project plan and conceivably meet the requirements of Stage 1 meaningful use. But, the question continued to loom; would they be successful long term with that approach? Or, should they convince the leadership that this was not an IT initiative but rather an operational and clinical project to change the workflows of the organization with information technology as the enabler. It would take IT out of the driver's seat and put it in the hands of operations. It would also push the organization up against the penalty phase of the HITECH Act. The next EMR executive steering committee meeting was next week. If they were going to propose a change in direction, this would be the meeting to launch the idea.

\section{Acknowledgements}

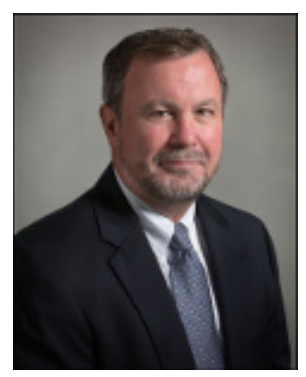

Mark Hulse, R.N., is the vice president of information technology and chief information officer at Moffitt. He directs the development and implementation of information systems initiatives. Hulse previously served as the vice president and CIO of North Shore Medical Center in Massachusetts for six years. His experience in implementing electronic medical records and computerized physician order entry is important to Moffitt as it uses technology to provide the best care and customer service to patients.

\section{Biography}

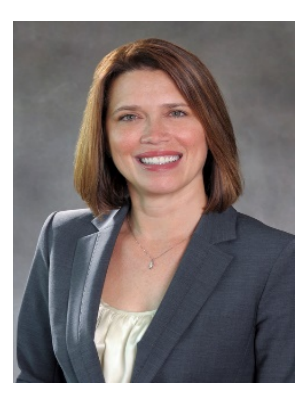

Janene Culumber currently serves as the chief financial officer for Florida Orthopaedic Institute and for Florida Orthopaedic Institute Surgery Center. She also serves as a Supervisory Committee Member of the USF Federal Credit Union. Culumber previously served as senior vice president and chief financial officer for Moffitt Cancer Center. Prior to joining Moffitt, Culumber was a senior manager in the audit practice of KPMG LLP. She is a graduate of the University of Florida, where she earned a Master's of Accountancy and a Bachelor's of Science in Accounting.

\section{References}

Jha, A. K. (2010). Meaningful use of electronic health records: The road ahead. JAMA, 304(15), 17091710. doi: 10.1001/jama.2010.1497

Meaningful Use. (2012). Retrieved from http://www.cdc.gov/ehrmeaningfuluse/introduction.html

Rosenbaum, S. (2011). The patient protection and affordable care act: Implications for public health policy and practice. Public Health Reports, (1974-), 126(1), 130-135. doi: 10.2307/41639332 


\section{Exhibit 1: Medicare EHR Incentive Payment Schedule for Eligible} Professionals ${ }^{2 *}$

- The program started in 2011 , and payments will continue through 2016. Eligible professionals can participate for up to 5 continuous years throughout the duration of the program.

- The last year to begin participation and receive an incentive payment is 2014 . To receive the maximum incentive payment, eligible professionals must have started participation by 2012 . Eligible professionals who demonstrate meaningful use of certified EHR technology can receive up to $\$ 43,720$ over 5 continuous years.

- To qualify for incentive payments, eligible professionals must successfully demonstrate meaningful use for each year of participation in the program.

- Beginning in 2015, eligible professionals who do not successfully demonstrate meaningful use will be subject to a payment adjustment. The payment reduction starts at $1 \%$ and increases each year that an eligible professional does not demonstrate meaningful use, to a maximum of $5 \%$.

\begin{tabular}{|c|c|c|c|c|}
\hline & $\begin{array}{c}\text { First Payment } \\
\text { Received in } 2011\end{array}$ & $\begin{array}{c}\text { First Payment } \\
\text { Received in } 2012\end{array}$ & $\begin{array}{c}\text { First Payment } \\
\text { Received in } 2013\end{array}$ & $\begin{array}{c}\text { First Payment } \\
\text { Received in } 2014\end{array}$ \\
\hline $\begin{array}{l}\text { Payment Amount } \\
\text { in } 2011\end{array}$ & $\$ 18,000$ & & & \\
\hline $\begin{array}{l}\text { Payment Amount } \\
\text { in } 2012\end{array}$ & $\$ 12,000$ & $\$ 18,000$ & & \\
\hline $\begin{array}{l}\text { Payment Amount } \\
\text { in } 2013\end{array}$ & $\$ 7,840$ & $\$ 11,760$ & $\$ 14,700$ & \\
\hline $\begin{array}{l}\text { Payment Amount } \\
\text { in } 2014\end{array}$ & $\$ 3,920$ & $\$ 7,840$ & $\$ 11,760$ & $\$ 11,760$ \\
\hline $\begin{array}{l}\text { Payment Amount } \\
\text { in } 2015\end{array}$ & $\$ 1,960$ & $\$ 3,920$ & $\$ 7,840$ & $\$ 7,840$ \\
\hline $\begin{array}{l}\text { Payment Amount } \\
\text { in } 2016\end{array}$ & & $\$ 1,960$ & $\$ 3,920$ & $\$ 3,920$ \\
\hline $\begin{array}{l}\text { TOTAL Incentive } \\
\text { Payments }\end{array}$ & $\$ 43,720$ & $\$ 43,480$ & $\$ 38,220$ & $\$ 23,520$ \\
\hline
\end{tabular}

*As required by law, President Obama issued a sequestration order on March 1, 2013. Under these mandatory reductions, Medicare EHR incentive payments made to eligible professionals and eligible hospitals will be reduced by $2 \%$. This $2 \%$ reduction has been applied to any Medicare EHR incentive payment for a reporting period that ended on or after April 1, 2013. This reduction does not apply to Medicaid EHR incentive payments.

${ }^{2}$ Source: http://www.cms.gov/Regulations-and-Guidance/Legislation/EHRIncentiveProgram/Basics.html 


\section{Exhibit 2: Meaningful Use Stage 1 vs. Stage 2 Comparison Table}

\begin{tabular}{|c|c|c|c|}
\hline \multicolumn{4}{|c|}{$\begin{array}{c}\text { Stage } 1 \text { vs. Stage } 2 \text { Comparison } \\
\text { Table for Eligible Professionals } \\
\text { Last Updated: August, } 2012\end{array}$} \\
\hline \multicolumn{4}{|c|}{ CORE OBJECTIVES (17 tołal) } \\
\hline Stage 1 Objective & Stage 1 Measure & Stage 2 Objective & Stage 2 Measure \\
\hline $\begin{array}{l}\text { Use CPOE for } \\
\text { medication orders } \\
\text { directly entered by any } \\
\text { licensed healthcare } \\
\text { professional who can } \\
\text { enter orders into the } \\
\text { medical record per } \\
\text { state, local and } \\
\text { professional guidelines }\end{array}$ & $\begin{array}{l}\text { More than } 30 \% \text { of } \\
\text { unique patients with at } \\
\text { least one medication in } \\
\text { their medication list } \\
\text { seen by the EP have at } \\
\text { least one medication } \\
\text { order entered using } \\
\text { CPOE }\end{array}$ & $\begin{array}{l}\text { Use computerized } \\
\text { provider order entry } \\
\text { (CPOE) for medication, } \\
\text { laboratory and radiology } \\
\text { orders directly entered } \\
\text { by any licensed } \\
\text { healthcare professional } \\
\text { who can enter orders } \\
\text { into the medical record } \\
\text { per state, local and } \\
\text { professional guidelines }\end{array}$ & $\begin{array}{l}\text { More than } 60 \% \text { of } \\
\text { medication, } 30 \% \text { of } \\
\text { laboratory, and } 30 \% \text { of } \\
\text { radiology orders created by } \\
\text { the EP during the EHR } \\
\text { reporting period are } \\
\text { recorded using CPOE }\end{array}$ \\
\hline $\begin{array}{l}\text { Implement drug-drug } \\
\text { and drug-allergy } \\
\text { interaction checks }\end{array}$ & $\begin{array}{l}\text { The EP has enabled } \\
\text { this functionality for } \\
\text { the entire EHR } \\
\text { reporting period }\end{array}$ & $\begin{array}{l}\text { No longer a separate } \\
\text { objective for stage } 2\end{array}$ & $\begin{array}{l}\text { This measure is } \\
\text { incorporated into the Stage } \\
2 \text { Clinical Decision Support } \\
\text { measure }\end{array}$ \\
\hline $\begin{array}{l}\text { Generate and transmit } \\
\text { permissible } \\
\text { prescriptions } \\
\text { electronically (eRx) }\end{array}$ & $\begin{array}{l}\text { More than } 40 \% \text { of all } \\
\text { permissible } \\
\text { prescriptions written } \\
\text { by the EP are } \\
\text { transmitted } \\
\text { electronically using } \\
\text { certified EHR } \\
\text { technology }\end{array}$ & $\begin{array}{l}\text { Generate and transmit } \\
\text { permissible prescriptions } \\
\text { electronically (eRx) }\end{array}$ & $\begin{array}{l}\text { More than } 50 \% \text { of all } \\
\text { permissible prescriptions } \\
\text { written by the EP are } \\
\text { compared to at least one } \\
\text { drug formulary and } \\
\text { transmitted electronically } \\
\text { using Certified EHR } \\
\text { Technology }\end{array}$ \\
\hline $\begin{array}{l}\text { Record demographics } \\
\text { - Preferred language } \\
\text { - } \text { Gender } \\
\text { - Race } \\
\text { - Ethnicity } \\
\text { - } \text { Date of birth }\end{array}$ & $\begin{array}{l}\text { More than } 50 \% \text { of all } \\
\text { unique patients seen } \\
\text { by the EP have } \\
\text { demographics } \\
\text { recorded as structured } \\
\text { data }\end{array}$ & $\begin{array}{l}\text { Record the following } \\
\text { demographics } \\
\text { - Preferred } \\
\text { language } \\
\text { - Gender } \\
\text { - Race } \\
\text { - Ethnicity } \\
\text { Date of birth }\end{array}$ & $\begin{array}{l}\text { More than } 80 \% \text { of all unique } \\
\text { patients seen by the EP } \\
\text { have demographics } \\
\text { recorded as structured data }\end{array}$ \\
\hline $\begin{array}{l}\text { Maintain an up-to-date } \\
\text { problem list of current }\end{array}$ & $\begin{array}{l}\text { More than } 80 \% \text { of all } \\
\text { unique patients seen }\end{array}$ & $\begin{array}{l}\text { No longer a separate } \\
\text { objective for stage } 2\end{array}$ & $\begin{array}{l}\text { This measure is } \\
\text { incorporated into the stage }\end{array}$ \\
\hline & & 1 & \\
\hline
\end{tabular}




\begin{tabular}{|c|c|c|c|}
\hline and active diagnoses & $\begin{array}{l}\text { by the EP have at least } \\
\text { one entry or an } \\
\text { indication that no } \\
\text { problems are known } \\
\text { for the patient } \\
\text { recorded as structured } \\
\text { data }\end{array}$ & & $\begin{array}{l}2 \text { measure of Summary of } \\
\text { Care Document at } \\
\text { Transitions of Care and } \\
\text { Referrals }\end{array}$ \\
\hline $\begin{array}{l}\text { Maintain active } \\
\text { medication list }\end{array}$ & $\begin{array}{l}\text { More than } 80 \% \text { of all } \\
\text { unique patients seen } \\
\text { by the EP have at least } \\
\text { one entry (or an } \\
\text { indication that the } \\
\text { patient is not currently } \\
\text { prescribed any } \\
\text { medication) recorded } \\
\text { as structured data }\end{array}$ & $\begin{array}{l}\text { No longer a separate } \\
\text { objective for stage } 2\end{array}$ & $\begin{array}{l}\text { This measure is } \\
\text { incorporated into the Stage } \\
2 \text { measure of Summary of } \\
\text { Care Document at } \\
\text { Transitions of Care and } \\
\text { Referrals }\end{array}$ \\
\hline $\begin{array}{l}\text { Maintain active } \\
\text { medication allergy list }\end{array}$ & $\begin{array}{l}\text { More than } 80 \% \text { of all } \\
\text { unique patients seen } \\
\text { by the EP have at least } \\
\text { one entry (or an } \\
\text { indication that the } \\
\text { patient has no known } \\
\text { medication allergies) } \\
\text { recorded as structured } \\
\text { data }\end{array}$ & $\begin{array}{l}\text { No longer a separate } \\
\text { objective for stage } 2\end{array}$ & $\begin{array}{l}\text { This measure is } \\
\text { incorporated into the Stage } \\
2 \text { measure of Summary of } \\
\text { Care Document at } \\
\text { Transitions of Care and } \\
\text { Referrals }\end{array}$ \\
\hline $\begin{array}{l}\text { Record and chart } \\
\text { changes in vital signs: } \\
\text { - Height } \\
\text { - Weight } \\
\text { - Blood pressure } \\
\text { - Calculate and } \\
\text { display BMI } \\
\text { - Plot and display } \\
\text { growth charts for } \\
\text { children 2-20 years, } \\
\text { including BMI }\end{array}$ & $\begin{array}{l}\text { For more than } 50 \% \text { of } \\
\text { all unique patients age } \\
2 \text { and over seen by the } \\
\text { EP, blood pressure, } \\
\text { height and weight are } \\
\text { recorded as structured } \\
\text { data }\end{array}$ & $\begin{array}{l}\text { Record and chart } \\
\text { changes in vital signs: } \\
\text { - Height } \\
\text { - Weight } \\
\text { - Blood pressure (age } \\
3 \text { and over) } \\
\text { - Calculate and display } \\
\text { BMI } \\
\text { Plot and display } \\
\text { growth charts for } \\
\text { patients 0-20 years, } \\
\text { including BMI }\end{array}$ & $\begin{array}{l}\text { More than } 80 \% \text { of all unique } \\
\text { patients seen by the EP } \\
\text { have blood pressure (for } \\
\text { patients age } 3 \text { and over } \\
\text { only) and height and weight } \\
\text { (for all ages) recorded as } \\
\text { structured data }\end{array}$ \\
\hline $\begin{array}{l}\text { Record smoking status } \\
\text { for patients } 13 \text { years old } \\
\text { or older }\end{array}$ & $\begin{array}{l}\text { More than } 50 \% \text { of all } \\
\text { unique patients } 13 \\
\text { years old or older seen } \\
\text { by the EP have } \\
\text { smoking status }\end{array}$ & $\begin{array}{l}\text { Record smoking status } \\
\text { for patients } 13 \text { years old } \\
\text { or older }\end{array}$ & $\begin{array}{l}\text { More than } 80 \% \text { of all unique } \\
\text { patients } 13 \text { years old or } \\
\text { older seen by the EP have } \\
\text { smoking status recorded as } \\
\text { structured data }\end{array}$ \\
\hline
\end{tabular}




\begin{tabular}{|c|c|c|c|}
\hline & $\begin{array}{l}\text { recorded as structured } \\
\text { data }\end{array}$ & & \\
\hline $\begin{array}{l}\text { Implement one clinical } \\
\text { decision support rule } \\
\text { relevant to specialty or } \\
\text { high clinical priority } \\
\text { along with the ability to } \\
\text { track compliance that } \\
\text { rule }\end{array}$ & $\begin{array}{l}\text { Implement one clinical } \\
\text { decision support rule }\end{array}$ & $\begin{array}{l}\text { Use clinical decision } \\
\text { support to improve } \\
\text { performance on high- } \\
\text { priority health conditions }\end{array}$ & $\begin{array}{l}\text { 1. Implement } 5 \text { clinical } \\
\text { decision support } \\
\text { interventions related to } \\
4 \text { or more clinical } \\
\text { quality measures, if } \\
\text { applicable, at a relevant } \\
\text { point in patient care for } \\
\text { the entire EHR reporting } \\
\text { period. } \\
\text { 2. The EP, eligible hospital, } \\
\text { or CAH has enabled the } \\
\text { functionality for drug- } \\
\text { drug and drug-allergy } \\
\text { interaction checks for } \\
\text { the entire EHR reporting } \\
\text { period }\end{array}$ \\
\hline $\begin{array}{l}\text { Report clinical quality } \\
\text { measures (COMs) to } \\
\text { CMS or the States }\end{array}$ & $\begin{array}{l}\text { Provide aggregate } \\
\text { numerator, } \\
\text { denominator, and } \\
\text { exclusions through } \\
\text { attestation or through } \\
\text { the PQRS Electronic } \\
\text { Reporting Pilot }\end{array}$ & $\begin{array}{l}\text { No longer a separate } \\
\text { objective for stage } 2 \text {, } \\
\text { but providers must still } \\
\text { submit cams to CMS or } \\
\text { the states in order to } \\
\text { achieve meaningful use }\end{array}$ & $\begin{array}{l}\text { Starting in 2014, all CQMs } \\
\text { will be submitted } \\
\text { electronically to CMS }\end{array}$ \\
\hline $\begin{array}{l}\text { Provide patients with an } \\
\text { electronic copy of their } \\
\text { health information } \\
\text { (including diagnostic } \\
\text { test results, problem } \\
\text { list, medication lists, } \\
\text { medication allergies), } \\
\text { upon request }\end{array}$ & $\begin{array}{l}\text { More than 50\% of all } \\
\text { patients of the EP who } \\
\text { request an electronic } \\
\text { copy of their health } \\
\text { information are } \\
\text { provided it within } 3 \\
\text { business days }\end{array}$ & $\begin{array}{l}\text { Provide patients the } \\
\text { ability to view online, } \\
\text { download and transmit } \\
\text { their health information } \\
\text { within four business days } \\
\text { of the information being } \\
\text { available to the EP }\end{array}$ & $\begin{array}{l}\text { i. More than } 50 \% \text { of all } \\
\text { unique patients seen by } \\
\text { the EP during the EHR } \\
\text { reporting period are } \\
\text { provided timely } \\
\text { (available to the patient } \\
\text { within } 4 \text { business days } \\
\text { after the information is } \\
\text { available to the EP) } \\
\text { online access to their } \\
\text { health information } \\
\text { ii. More than } 5 \% \text { of all } \\
\text { unique patients seen by } \\
\text { the EP during the EHR } \\
\text { reporting period (or } \\
\text { their authorized }\end{array}$ \\
\hline
\end{tabular}




\begin{tabular}{|c|c|c|c|}
\hline & & & $\begin{array}{l}\text { representatives) view, } \\
\text { download, or transmit } \\
\text { to a third party their } \\
\text { health information }\end{array}$ \\
\hline $\begin{array}{l}\text { Provide clinical } \\
\text { summaries for patients } \\
\text { for each office visit }\end{array}$ & $\begin{array}{l}\text { Clinical summaries } \\
\text { provided to patients } \\
\text { for more than } 50 \% \text { of } \\
\text { all office visits within } 3 \\
\text { business days }\end{array}$ & $\begin{array}{l}\text { Provide clinical } \\
\text { summaries for patients } \\
\text { for each office visit }\end{array}$ & $\begin{array}{l}\text { Clinical summaries provided } \\
\text { to patients within one } \\
\text { business day for more than } \\
50 \% \text { of office visits }\end{array}$ \\
\hline $\begin{array}{l}\text { Capability to exchange } \\
\text { key clinical information } \\
\text { (for example, problem } \\
\text { list, medication list, } \\
\text { medication allergies, } \\
\text { diagnostic test results), } \\
\text { among providers of } \\
\text { care and patient } \\
\text { authorized entities } \\
\text { electronically }\end{array}$ & $\begin{array}{l}\text { Performed at least one } \\
\text { test of certified EHR } \\
\text { technology's capacity } \\
\text { to electronically } \\
\text { exchange key clinical } \\
\text { information }\end{array}$ & $\begin{array}{l}\text { This objective is } \\
\text { eliminated from Stage } 1 \\
\text { in } 2013 \text { and is no longer } \\
\text { an objective for stage } 2\end{array}$ & $\begin{array}{l}\text { This measure is eliminated } \\
\text { from stage } 1 \text { in } 2013 \text { and is } \\
\text { no longer a measure for } \\
\text { stage } 2\end{array}$ \\
\hline $\begin{array}{l}\text { Protect electronic } \\
\text { health information } \\
\text { created or maintained } \\
\text { by the certified EHR } \\
\text { technology through the } \\
\text { implementation of } \\
\text { appropriate technical } \\
\text { capabilities }\end{array}$ & $\begin{array}{l}\text { Conduct or review a } \\
\text { security risk analysis } \\
\text { per } 45 \text { CFR } 164.308 \\
\text { (a)(1) and implement } \\
\text { security updates as } \\
\text { necessary and correct } \\
\text { identified security } \\
\text { deficiencies as part of } \\
\text { its risk management } \\
\text { process }\end{array}$ & $\begin{array}{l}\text { Protect electronic health } \\
\text { information created or } \\
\text { maintained by the } \\
\text { Certified EHR Technology } \\
\text { through the } \\
\text { implementation of } \\
\text { appropriate technical } \\
\text { capabilities. }\end{array}$ & $\begin{array}{l}\text { Conduct or review a } \\
\text { security risk analysis in } \\
\text { accordance with the } \\
\text { requirements under } 45 \text { CFR } \\
164.308 \text { (a)(1), including } \\
\text { addressing the } \\
\text { encryption/security of data } \\
\text { at rest and implement } \\
\text { security updates as } \\
\text { necessary and correct } \\
\text { identified security } \\
\text { deficiencies as part of its } \\
\text { risk management process }\end{array}$ \\
\hline $\begin{array}{l}\text { Implement drug- } \\
\text { formulary checks }\end{array}$ & $\begin{array}{l}\text { The EP has enabled } \\
\text { this functionality and } \\
\text { has access to at least } \\
\text { one internal or } \\
\text { external drug } \\
\text { formulary for the } \\
\text { entire EHR reporting } \\
\text { period }\end{array}$ & $\begin{array}{l}\text { No longer a separate } \\
\text { objective for stage } 2\end{array}$ & $\begin{array}{l}\text { This measure is } \\
\text { incorporated into the e- } \\
\text { Prescribing measure for } \\
\text { stage } 2\end{array}$ \\
\hline
\end{tabular}




\begin{tabular}{|c|c|c|c|}
\hline $\begin{array}{l}\text { Incorporate clinical lab- } \\
\text { test results into certified } \\
\text { EHR technology as } \\
\text { structured data }\end{array}$ & $\begin{array}{l}\text { More than } 40 \% \text { of all } \\
\text { clinical lab tests results } \\
\text { ordered by the EP } \\
\text { during the EHR } \\
\text { reporting period } \\
\text { whose results are } \\
\text { either in a } \\
\text { positive/negative or } \\
\text { numerical format are } \\
\text { incorporated in } \\
\text { certified EHR } \\
\text { technology as } \\
\text { structured data }\end{array}$ & $\begin{array}{l}\text { Incorporate clinical lab- } \\
\text { test results into certified } \\
\text { EHR Technology as } \\
\text { structured data }\end{array}$ & $\begin{array}{l}\text { More than } 55 \% \text { of all clinical } \\
\text { lab tests results ordered by } \\
\text { the EP during the EHR } \\
\text { reporting period whose } \\
\text { results are either in a } \\
\text { positive/negative or } \\
\text { numerical format are } \\
\text { incorporated in certified } \\
\text { EHR Technology as } \\
\text { structured data }\end{array}$ \\
\hline $\begin{array}{l}\text { Generate lists of } \\
\text { patients by specific } \\
\text { conditions to use for } \\
\text { quality improvement, } \\
\text { reduction of disparities, } \\
\text { research or outreach }\end{array}$ & $\begin{array}{l}\text { Generate at least one } \\
\text { report listing patients } \\
\text { of the EP with a } \\
\text { specific condition }\end{array}$ & $\begin{array}{l}\text { Generate lists of patients } \\
\text { by specific conditions to } \\
\text { use for quality } \\
\text { improvement, reduction } \\
\text { of disparities, research, } \\
\text { or outreach }\end{array}$ & $\begin{array}{l}\text { Generate at least one } \\
\text { report listing patients of the } \\
\text { EP with a specific condition }\end{array}$ \\
\hline $\begin{array}{l}\text { Send reminders to } \\
\text { patients per patient } \\
\text { preference for } \\
\text { preventive/ follow up } \\
\text { care }\end{array}$ & $\begin{array}{l}\text { More than } 20 \% \text { of all } \\
\text { unique patients } 65 \\
\text { years or older or } 5 \\
\text { years old or younger } \\
\text { were sent an } \\
\text { appropriate reminder } \\
\text { during the EHR } \\
\text { reporting period }\end{array}$ & $\begin{array}{l}\text { Use clinically relevant } \\
\text { information to identify } \\
\text { patients who should } \\
\text { receive reminders for } \\
\text { preventive/follow-up } \\
\text { care }\end{array}$ & $\begin{array}{l}\text { Use EHR to identify and } \\
\text { provide reminders for } \\
\text { preventive/follow-up care } \\
\text { for more than } 10 \% \text { of } \\
\text { patients with two or more } \\
\text { office visits in the last } 2 \\
\text { years }\end{array}$ \\
\hline $\begin{array}{l}\text { Provide patients with } \\
\text { timely electronic access } \\
\text { to their health } \\
\text { information (including } \\
\text { lab results, problem list, } \\
\text { medication lists, } \\
\text { medication allergies) } \\
\text { within four business } \\
\text { days of the information } \\
\text { being available to the EP }\end{array}$ & $\begin{array}{l}\text { More than } 10 \% \text { of all } \\
\text { unique patients seen } \\
\text { by the EP are provided } \\
\text { timely (available to the } \\
\text { patient within four } \\
\text { business days of being } \\
\text { updated in the } \\
\text { certified EHR } \\
\text { technology) electronic } \\
\text { access to their health } \\
\text { information subject to } \\
\text { the EP's discretion to } \\
\text { withhold certain } \\
\text { information }\end{array}$ & $\begin{array}{l}\text { This objective is } \\
\text { eliminated from stage } 1 \\
\text { in } 2014 \text { and is no longer } \\
\text { an objective for stage } 2\end{array}$ & $\begin{array}{l}\text { This measure is eliminated } \\
\text { from stage } 1 \text { in } 2014 \text { and is } \\
\text { no longer a measure for } \\
\text { stage } 2\end{array}$ \\
\hline
\end{tabular}


Use certified EHR

technology to identify

patient-specific

education resources and

provide those resources

to the patient if

appropriate

The EP who receives a patient from another

setting of care or

provider of care or

believes an encounter is

relevant should perform

medication

reconciliation

The EP who transitions

their patient to another

setting of care or

provider of care or

refers their patient to

another provider of care

should provide

summary of care record

for each transition of

care or referral

\section{More than $10 \%$ of all}

unique patients seen

by the EP are provided

patient-specific

education resources

The EP performs

medication

reconciliation for more

than $50 \%$ of transitions

of care in which the

patient is transitioned

into the care of the EP

The EP who transitions

or refers their patient

to another setting of

care or provider of

care provides a

summary of care

record for more than

$50 \%$ of transitions of

care and referrals
Use certified EHR

technology to identify

patient-specific

education resources and

provide those resources

to the patient if

appropriate

The EP who receives a patient from another

setting of care or

provider of care or

believes an encounter is

relevant should perform

medication reconciliation

The EP who transitions

their patient to another

setting of care or

provider of care or refers

their patient to another

provider of care should

provide summary of care

record for each

transition of care or

referral
Patient-specific education

resources identified by

CEHRT are provided to

patients for more than $10 \%$

of all unique patients with

office visits seen by the EP

during the EHR reporting

period

The EP performs medication reconciliation for more than $50 \%$ of transitions of care in which the patient is

transitioned into the care of the EP

1. The EP who transitions or refers their patient to another setting of care or provider of care provides a summary of care record for more than $50 \%$ of transitions of care and referrals

2. The EP who transitions or refers their patient to another setting of care or provider of care provides a summary of care record either a) electronically transmitted to a recipient using CEHRT or b) where the recipient receives the summary of care record via exchange facilitated by an organization that is a NwHIN Exchange participant or is validated through an 


\begin{tabular}{|c|c|c|c|}
\hline & & & $\begin{array}{l}\text { ONC-established } \\
\text { governance mechanism } \\
\text { to facilitate exchange } \\
\text { for } 10 \% \text { of transitions } \\
\text { and referrals } \\
\text { 3. The EP who transitions } \\
\text { or refers their patient to } \\
\text { another setting of care } \\
\text { or provider of care must } \\
\text { either a) conduct one or } \\
\text { more successful } \\
\text { electronic exchanges of } \\
\text { a summary of care } \\
\text { record with a recipient } \\
\text { using technology that } \\
\text { was designed by a } \\
\text { different EHR developer } \\
\text { than the sender's, or b) } \\
\text { conduct one or more } \\
\text { successful tests with the } \\
\text { CMS-designated test } \\
\text { EHR during the EHR } \\
\text { reporting period }\end{array}$ \\
\hline $\begin{array}{l}\text { Capability to submit } \\
\text { electronic data to } \\
\text { immunization registries } \\
\text { or Immunization } \\
\text { Information systems } \\
\text { and actual submission } \\
\text { except where } \\
\text { prohibited and in } \\
\text { accordance with } \\
\text { applicable law and } \\
\text { practice }\end{array}$ & $\begin{array}{l}\text { Performed at least one } \\
\text { test of certified EHR } \\
\text { technology's capacity } \\
\text { to submit electronic } \\
\text { data to immunization } \\
\text { registries and follow } \\
\text { up submission if the } \\
\text { test is successful } \\
\text { (unless none of the } \\
\text { immunization } \\
\text { registries to which the } \\
\text { EP submits such } \\
\text { information have the } \\
\text { capacity to receive the } \\
\text { information } \\
\text { electronically) }\end{array}$ & $\begin{array}{l}\text { Capability to submit } \\
\text { electronic data to } \\
\text { immunization registries } \\
\text { or Immunization } \\
\text { Information Systems and } \\
\text { actual submission except } \\
\text { where prohibited and in } \\
\text { accordance with } \\
\text { applicable law and } \\
\text { practice }\end{array}$ & $\begin{array}{l}\text { Successful ongoing } \\
\text { submission of electronic } \\
\text { immunization data from } \\
\text { Certified EHR Technology to } \\
\text { an immunization registry or } \\
\text { immunization information } \\
\text { system for the entire EHR } \\
\text { reporting period }\end{array}$ \\
\hline NEW & NEW & $\begin{array}{l}\text { Use secure electronic } \\
\text { messaging to }\end{array}$ & $\begin{array}{l}\text { A secure message was sent } \\
\text { using the electronic }\end{array}$ \\
\hline
\end{tabular}




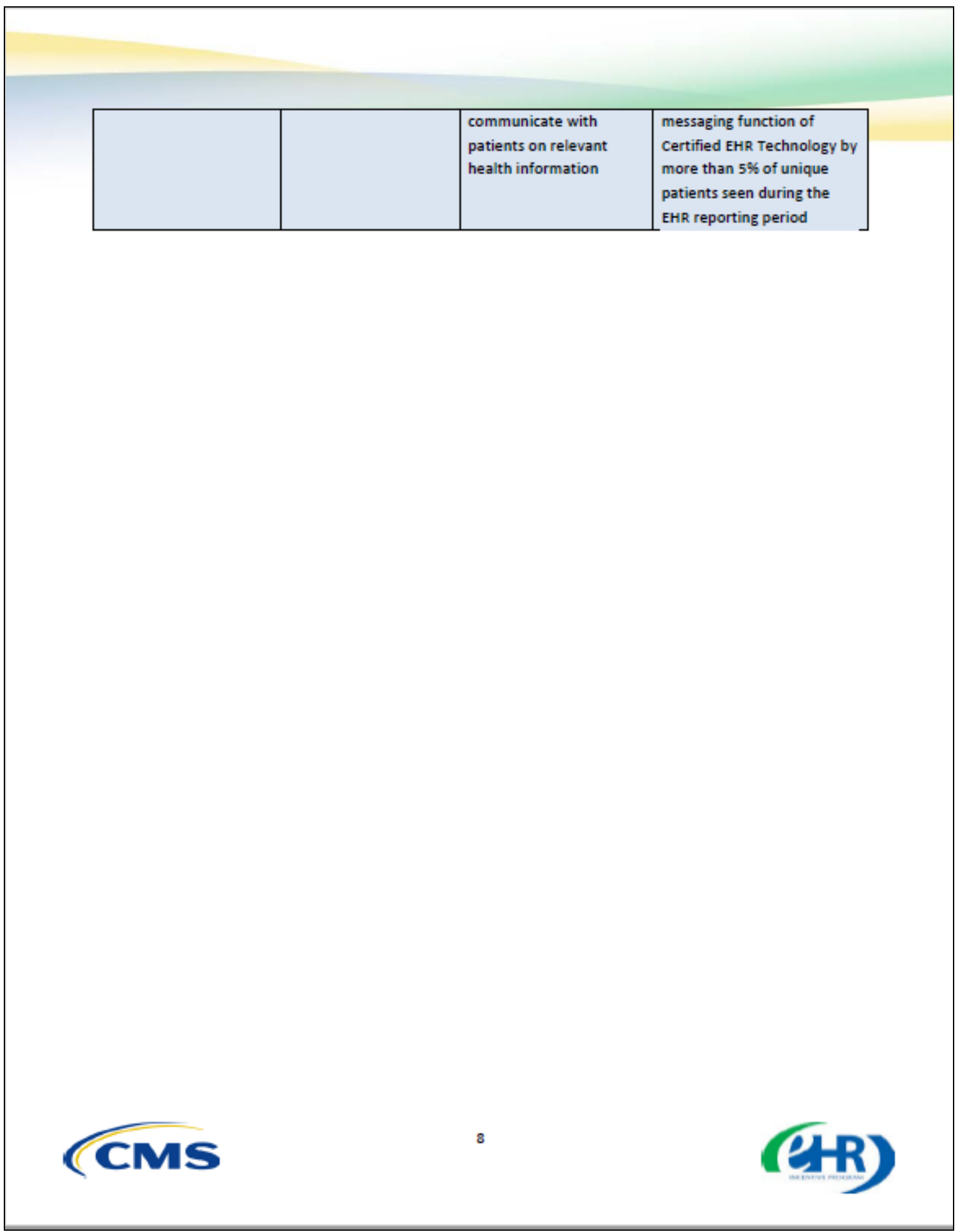




\section{MENU OBJECTIVES (EPs must select 3 of 6 menu objectives)}

\begin{tabular}{|c|c|c|c|}
\hline Stage 1 Objective & Stage 1 Measure & Stage 2 Objeclive & Stage 2 Measure \\
\hline $\begin{array}{l}\text { Capability to submit } \\
\text { electronic syndromic } \\
\text { surveillance data to } \\
\text { public health agencies } \\
\text { and actual submission } \\
\text { except where prohibited } \\
\text { and in accordance with } \\
\text { applicable law and } \\
\text { practice }\end{array}$ & $\begin{array}{l}\text { Performed at least } \\
\text { one test of certified } \\
\text { EHR technology's } \\
\text { capacity to provide } \\
\text { electronic syndromic } \\
\text { surveillance data to } \\
\text { public health agencies } \\
\text { and follow-up } \\
\text { submission if the test } \\
\text { is successful (unless } \\
\text { none of the public } \\
\text { health agencies to } \\
\text { which an EP, eligible } \\
\text { hospital or CAH } \\
\text { submits such } \\
\text { information have the } \\
\text { capacity to receive the } \\
\text { information } \\
\text { electronically) }\end{array}$ & $\begin{array}{l}\text { Capability to submit } \\
\text { electronic syndromic } \\
\text { surveillance data to } \\
\text { public health agencies } \\
\text { and actual submission } \\
\text { except where prohibited } \\
\text { and in accordance with } \\
\text { applicable law and } \\
\text { practice }\end{array}$ & $\begin{array}{l}\text { Successful ongoing submission } \\
\text { of electronic syndromic } \\
\text { surveillance data from } \\
\text { Certified EHR Technology to a } \\
\text { public health agency for the } \\
\text { entire EHR reporting period }\end{array}$ \\
\hline NEW & NEW & $\begin{array}{l}\text { Record electronic notes } \\
\text { in patient records }\end{array}$ & $\begin{array}{l}\text { Enter at least one electronic } \\
\text { progress note created, edited } \\
\text { and signed by an EP for more } \\
\text { than } 30 \% \text { of unique patients }\end{array}$ \\
\hline NEW & NEW & $\begin{array}{l}\text { Imaging results } \\
\text { consisting of the image } \\
\text { itself and any } \\
\text { explanation or other } \\
\text { accompanying } \\
\text { information are } \\
\text { accessible through } \\
\text { CEHRT }\end{array}$ & $\begin{array}{l}\text { More than } 10 \% \text { of all scans and } \\
\text { tests whose result is an image } \\
\text { ordered by the EP for patients } \\
\text { seen during the EHR reporting } \\
\text { period are incorporated into or } \\
\text { accessible through certified } \\
\text { EHR Technology }\end{array}$ \\
\hline NEW & NEW & $\begin{array}{l}\text { Record patient family } \\
\text { health history as } \\
\text { structured data }\end{array}$ & $\begin{array}{l}\text { More than } 20 \% \text { of all unique } \\
\text { patients seen by the EP during } \\
\text { the EHR reporting period have } \\
\text { a structured data entry for one } \\
\text { or more first-degree relatives } \\
\text { or an indication that family } \\
\text { health history has been }\end{array}$ \\
\hline \multicolumn{4}{|c|}{9} \\
\hline
\end{tabular}

Source: CMS website accessed on May 10, 2015 at http://www.cms.gov/Regulations-andGuidance/Legislation/EHRIncentivePrograms/Downloads/Stage1vsStage2CompTablesforEP.pdf 


\section{Exhibit 3: Moffitt's Interdisciplinary Departments ${ }^{3}$}

\section{Moffitt's Interdisciplinary Approach}

\begin{abstract}
Moffitt takes a full-service approach to patient care, bringing together experts from a variety of oncology specialties to determine the best treatment plan for each patient while linking together the Center's extensive array of medical and cancer support services.

Moffitt's interdisciplinary team approach and services are unique to the community and region and are an integral part of the Center's goal of providing the highest level of total cancer care.
\end{abstract}

\section{Patient Care Programs}

Interdisciplinary Patient Care Programs focus on specific types of cancer and include:

- Blood and Marrow Transplant

- Comprehensive Breast Cancer

- Cutaneous Oncology

- Endocrine Tumor

- Gastrointestinal Oncology

- Genitourinary Oncology

- Gynecologic Oncology

- Head \& Neck Oncology

- Internal and Hospital Medicine

- Malignant Hematology

- Neuro-Oncology

- Psychosocial and Palliative Care

- Radiation Oncology

- Sarcoma

- Senior Adult Oncology

- Survivorship Program

- Thoracic Oncology

${ }^{3}$ Excerpted from Moffitt Cancer Center website, Moffitt-Welcome-Book-030212, accessed on May $7^{\text {th }}$, 2015. http://moffitt.org/File\%20Library/Main\%20Nav/Home/Patient\%20Family\%20Orientation/MoffittWelcome-Book-030212.pdf. 


\section{Exhibit 4: Moffitt's EHR Adoption Curve ${ }^{4}$}

\section{EHR Monthly Status Roll-up - August 2013}

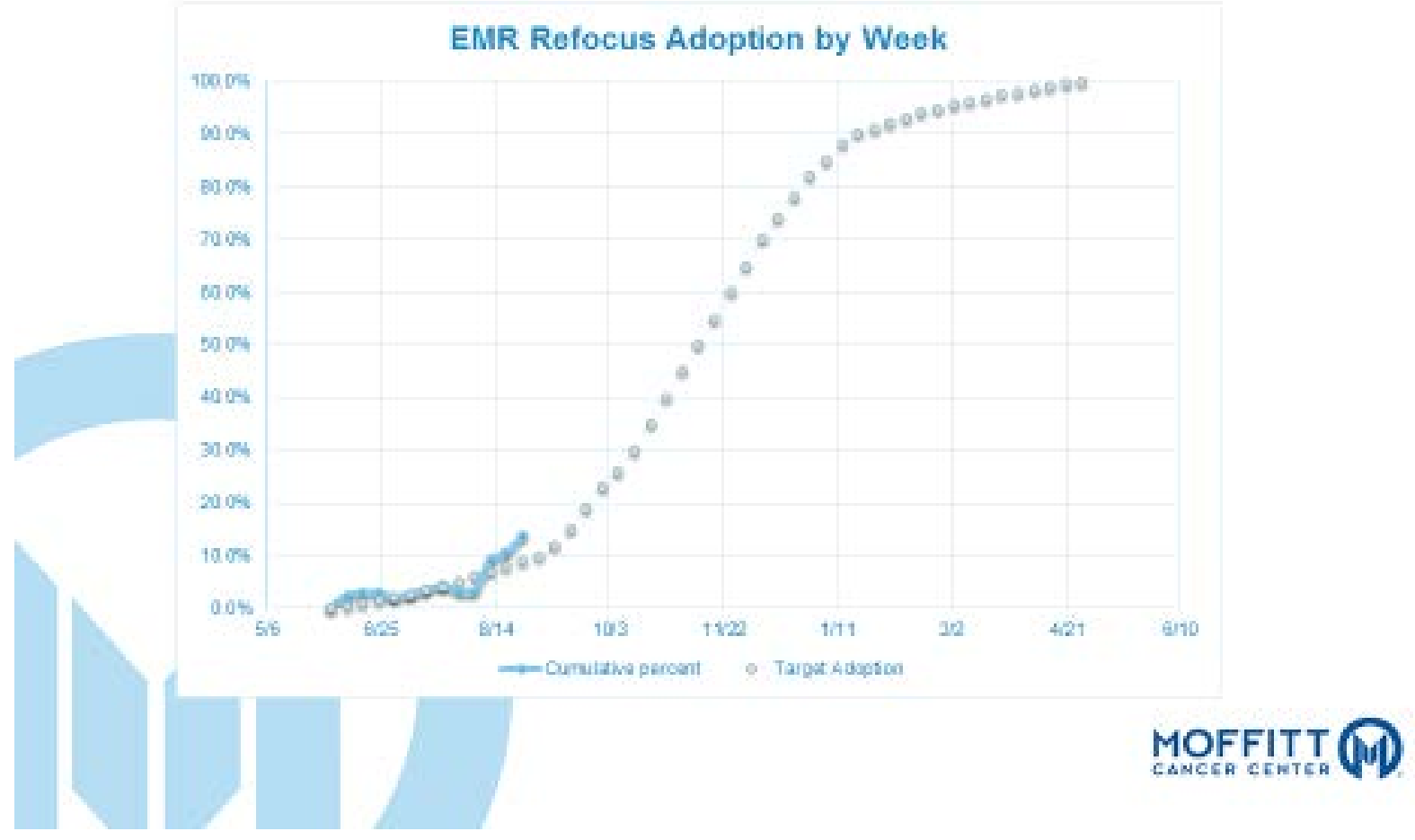

${ }^{4}$ Excerpted from Moffitt Cancer Center internal presentation to the EHR Steering Committee. 